\title{
ONE CONTRIBUTION TO THE FRICTION INVESTIGATION IN BULK METAL FORMING
}

\author{
Igor Kačmarčik*, Dejan Movrin, Aljoša Ivanišević \\ University of Novi Sad, Faculty of technical science, Serbia
}

\begin{abstract}
Friction is resistance to relative motion when one body slides over another. In metal forming operations, both sheet metal and bulk metal forming, friction is undesirable but also unavoidable occurrence. It has negative impact on main process parameters as well as on workpiece quality. In order to obtain accurate results in metal forming experiments or simulations, the precise value of friction has to be known. In this paper several methods for friction evaluations, such as ring test, forward bar extrusion, backward - forward hollow extrusion, twist extrusion are presented and analyzed. A new double backward extrusion model is proposed.
\end{abstract}

Key words: Friction models, Ring test, Friction calibration curves, Double backward extrusion

\section{INTRODUCTION}

In metal forming friction occurs due to relative motion between the workpiece material and the material of tools and dies. Assessment of friction in bulk metal forming operations is essential, as it influences almost all process parameters (forming load, effective stresses, material flow, temperature, workpiece quality and integrity, die wear...).

Main factors which affect magnitude of friction are: normal stresses in the process, relative velocity, lubrication, surface quality of tools, process temperature and mechanical properties of billet and tool material. In most cases friction is undesirable phenomenon, but unfortunately it is also unavoidable. Although it is not possible to eliminate it, friction can be significantly reduced by using lubrication, by using tools made from low adhesion materials or by applying ultrasonic vibrations to originate a gap between tools and workpiece [1],[2].

In order to withstand high pressures and forces which occur in metal forming, high performance lubricants are a necessity in modern production. Conventional lubricants used in bulk metal forming are based on phosphate coatings in combination with some additional substances, usually heavy metals. Most commonly used substance in phosphate coatings is zinc. However, these types of lubricants are not environmentally friendly. The best eco-friendly solutions for lubrication are

*Corresponding author's email: igorkac@uns.ac.rs 
dry manufacturing or manufacturing with lubricants that are made from substances in nature. Therefore, green metal forming should be processes where no polluting materials are produced. Main future trend in eco-lubrications is shift to light metals or non-metallic materials [3]. Today, modern and eco-friendly lubrication solutions include substances such as: electrolytic phosphate coating, micro porous coating, dual bath systems, single bath systems, etc [4],[5],[6].

\section{FRICTION MODELS}

Three most commonly used mathematical models for friction quantification are: Coulomb model, Constant friction model and General friction model. Several variations of these models are presented in [7],[8],[9].

In Coulomb model, friction shear stress is proportional to the normal stress. Friction coefficient " $\mu$ " is used to express friction shear factor $\left(\tau_{f}\right)$ :

$\tau_{f}=\mu \cdot p$

where $p$ is normal stress. Coulomb model is mainly used in processes with low pressures $\left(\mathrm{p} / \sigma_{0}<1,5\right.$, where $\sigma_{0}$ is flow stress of the material) [9]. This friction model occasionally gives an overestimation of friction stress, because the normal pressure is often considerably greater than the yield stress of the material. This phenomenon occurs in high pressure processes [7].

In Constant friction model friction shear stress is obtained from following expression:

$\tau_{f}=m \cdot \tau_{\max }$

where " $\mathrm{m}$ " is friction factor $(0<\mathrm{m}<1)$, and $\tau_{\max }$ is the yield stress of the material in pure shear. Constant friction model is adequate for processes where high effective strains and pressures prevail $\left(\mathrm{p} / \sigma_{0}>4\right)$ [9]. Setback of this model is that it overestimates friction stress at low pressures [7]. The comparisons between Coulomb friction model and Constant friction model are given in [8],[10].

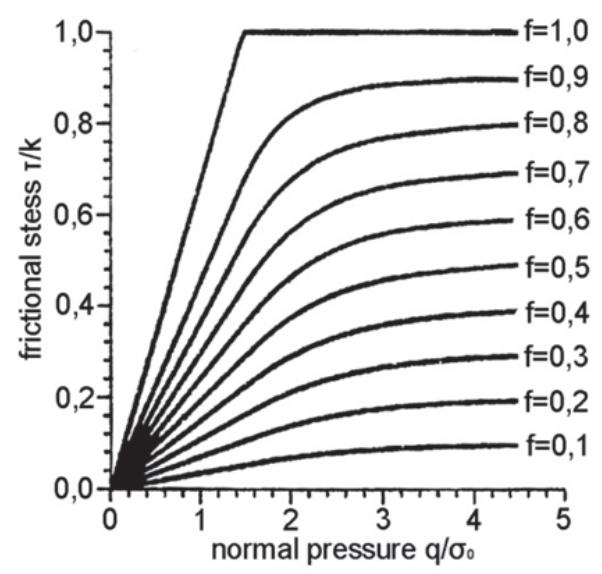

Figure 1 - Friction stress in general friction model [7] 
General friction model presented in [11] states:

$\tau=f \alpha k$

where $\tau$ is the friction stress, $\mathrm{f}$ is the friction factor expressing the friction in real contact $(0 \leq \mathrm{f} \leq 1), k$ is shear flow stress and $\alpha$ is real to apparent contact area ratio. In this model friction is proportional to normal stress at low pressures and fairly constant at high pressures (Figure 1). This model is a combination of previous two. A numerical comparison between friction models by finite volume method is presented in [12].

\section{EXPERIMENTAL METHODS FOR FRICTION ASSESMENT}

In experimental determination of friction, several experimental techniques have been developed, such as: ring-compression test, forward bar extrusion, backward cup extrusion, twist extrusion etc.

Ring - compression test is the most used method for friction determination. In this test ringshaped billet is compressed with two parallel plates (Figure 2a). Material flow in the ring is depended on the friction coefficient:

(a) All material flows outwards (Figure 2b) - low friction

(b) Material flows both outwards and inwards (Figure 2c) - high friction

At neutral radius no material flow in radial direction takes place. In case (a), neutral radius is smaller than inner radius and in case (b), neutral radius is between inner and outer radius.

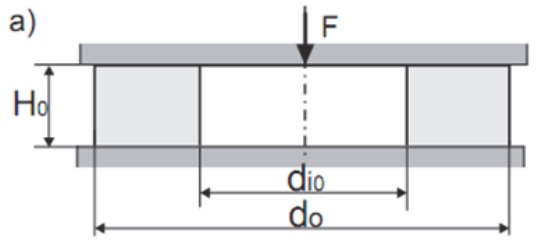

b)

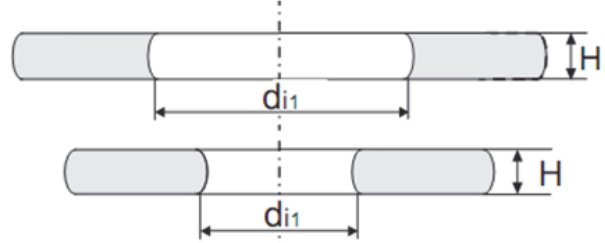

Figure 2 - Ring - compression test

In ring - test the ring is initially lubricated and placed between the top and bottom tool and compressed by a specific incremental value (for example, the height of the ring is reduced by $10 \%)$. Then the inner diameter, as well as ring's height is measured, and effective strains are calculated. Afterwards, ring is compressed again and the same procedure is repeated several times. With data obtained, friction curve $(\varepsilon \mathrm{d} \%-\varepsilon \mathrm{H} \%)$ can be imposed on fiction calibration curves and thereby, friction can be estimated. Friction calibration curves can be obtained by different methods.

This test was originally proposed by Kunogi [13] as a simple and fast method for comparing lubricant properties in forging. Male and Cockroft [14] later established first friction calibration curves (FCC) for this test based on experimental and theoretical analysis. Avitzur [15] and Hawyard and Jonson [16] obtained FCC by using only theoretical analysis. These authors assumed that in ring uniform deformation (no barreling) and constant interface frictional shear factor take place. Effects of barreling on FCC were investigated in [17].

Male and Cockroft [14] friction calibration curves are shown in Figure 3a. Friction calibration curves obtained by Avitzur's upper bound approach are shown in Figure 3b [15],[18]. 
a)

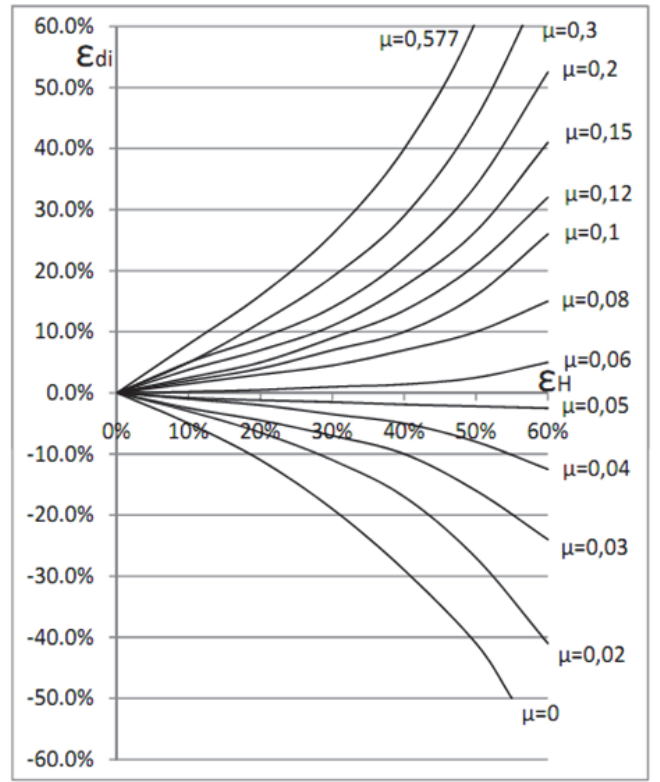

b)

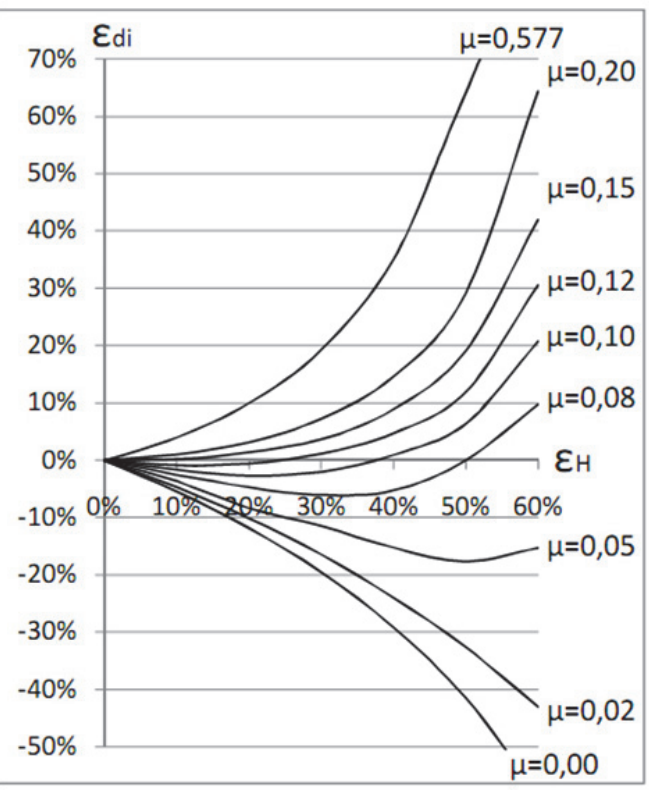

Figure 3 - Friction calibration curves obtained by Male and Cockroft (a) and Avitzur (b) [14], [15]

In order to obtain friction coefficient several incremental compressions have to be performed. Generally, a standard 6:3:2 (outer diameter - inner diameter - height) shape of the ring is used. Also, alternative billet ratios $(6: 3: 3,6: 3: 1$, etc.) and non-cylindrical shapes are used [7],[19],[20],[21],[22].

In [7] a new ring geometry shape shown in Figure 4 was proposed. In this model, normal stresses over some areas of the tool/workpiece interface are lower than the material's yield stress.

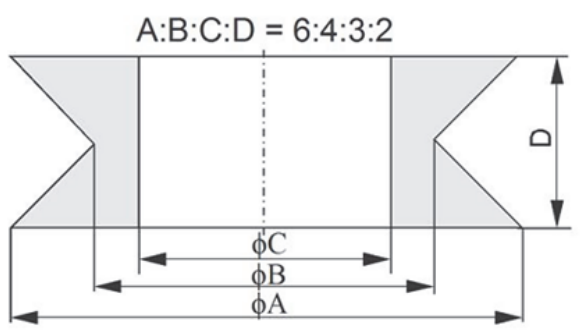

Figure 4 - New proposed shape for ring - test [7]

Another method of determining friction calibration curves is numerical simulation. In this method, simulation of ring compression is performed in appropriate FE software (e.g. Simufact Forming, Abaqus, Deform, AutoForm) by using same process parameters as in experiment and only varying friction coefficient. Friction calibration curves obtained in Simufact Forming 9.0 and Simufact Forming GP (ex Marc) are shown in Figure 5 [23]. 


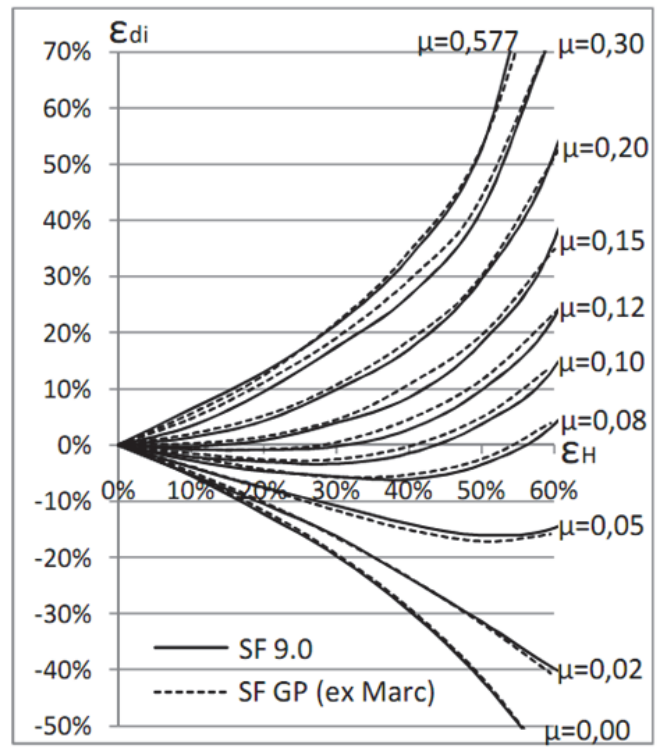

Figure 5 - FC chart obtained by Simufact Forming 9.0 and Simufact Forming GP (ex Marc) [23]

Numerical FE simulations [23] as well as works [14],[15],[18] have indicated that material of the billet does not influence the friction calibration curves.
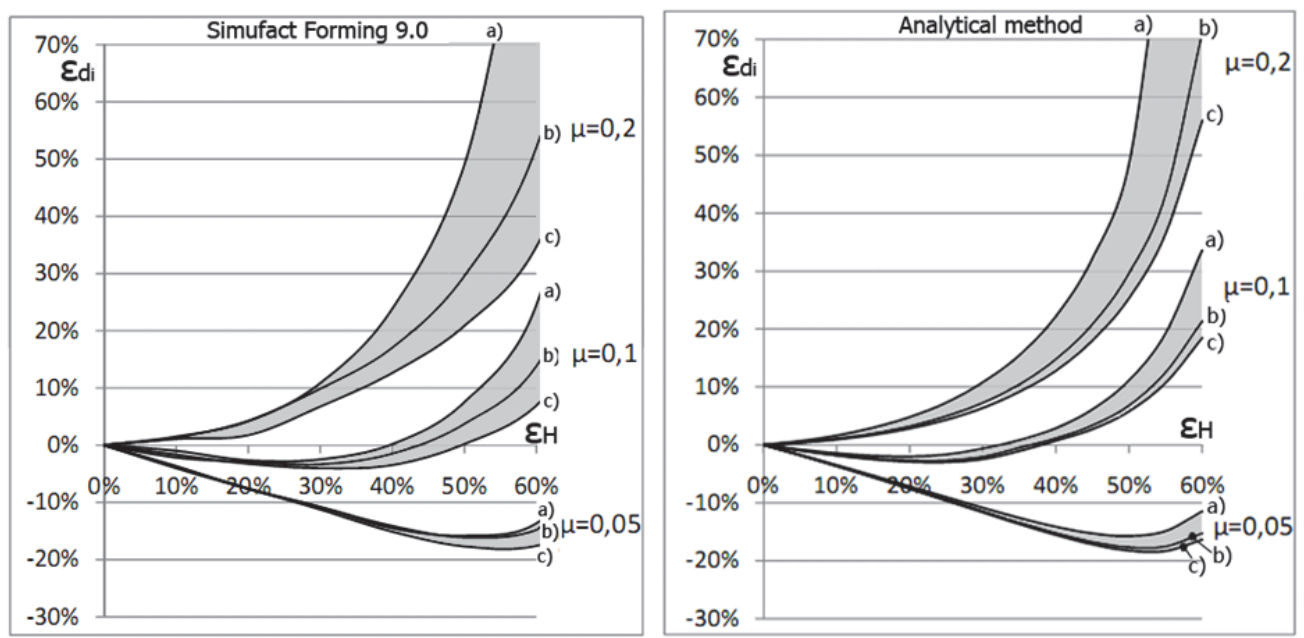

Figure 6-FCC for different inner ring diameters $(a-30: 12: 10 \mathrm{~mm}, b-30: 15: 10 \mathrm{~mm}$, c - 30:18:10 mm) in FEM simulation (left) and analytical calculations (right) [24]

Influence of ring's initial geometry ratio on FCC is presented in Figure 6. FCC obtained by simulation in Simufact Forming 9.0 for different friction values and ring's inner diameters are presented on the left side in Figure 6 and FCC obtained by Avitzur's upper bound approach on the 
right. It can be concluded that in first compression stages, there is no significant differences between FC curves obtained by simulation and analytics for different inner diameters. Also, results show that the lower the inner diameter, the lower the appropriate FC curve. FCC obtained by analytical and numerical method resemble very good (Figure 6).

In Figure 7 the influence of ring's initial thickness on FC curves is shown. Unlike in inner diameter variation, different ring's initial thickness results in instant disunion of FCC starting from the very beginning of the ring compression. It can be also seen that the higher the ring, the lower the corresponding FC curve for a given friction coefficient.
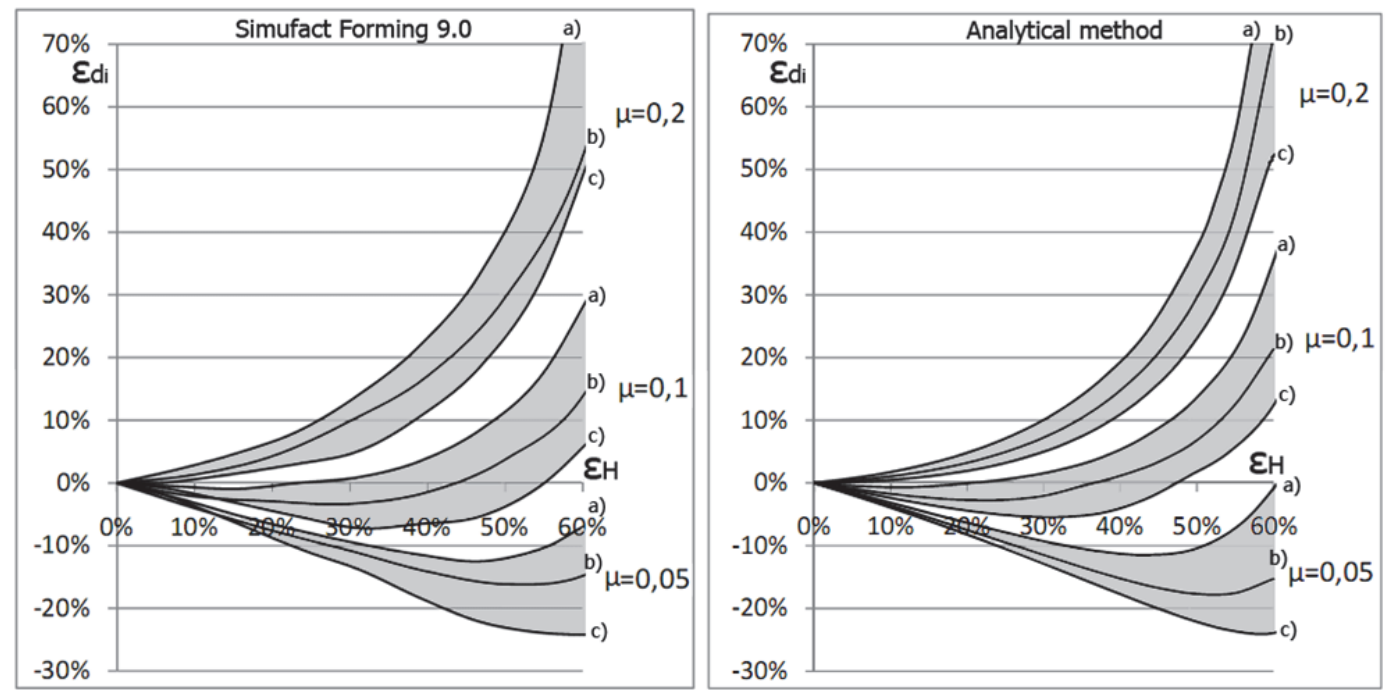

Figure 7- FCC for different ring thicknesses ( $a-30: 15: 8 \mathrm{~mm}, b-30: 15: 10 \mathrm{~mm}, c-30: 15: 12 \mathrm{~mm}$ ) in FEM simulation (left) and analytical calculations (right) [24]

Great advantage of ring - test is no need for force measurement, nor knowledge of yield stress of the material. Another asset is that this process is cheap and quick to perform as it uses simple tools and billets.

Although ring - compression test represents a good method for friction determination for processes with relatively small pressures, due to small effective strains in the test, several other models have been developed in which higher strains prevail and therefore better correspondence to industry processes is present. Another disadvantage of the ring test is the difficulty to determine friction in small ring reduction as the curves in their early stage are almost identical for similar friction coefficients [25].

In the Metal Forming Laboratory, University Novi Sad, extensive investigations on friction in bulk metal forming have been conducted. In Figure 8a ring - test samples are given and Figure 8b shows ring - compression process. Results of these investigations are presented in relevant literature [5],[23],[24],[26],[27]. 
a)

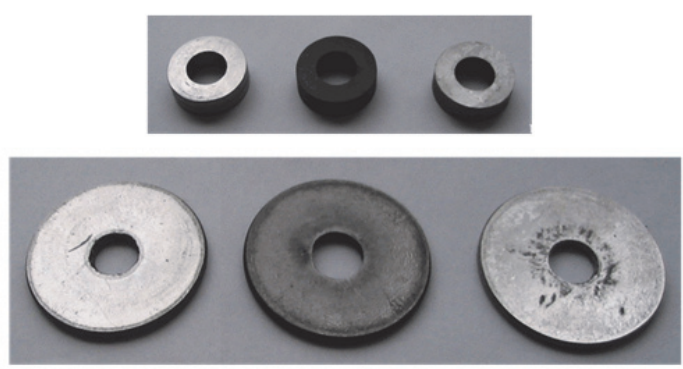

b)

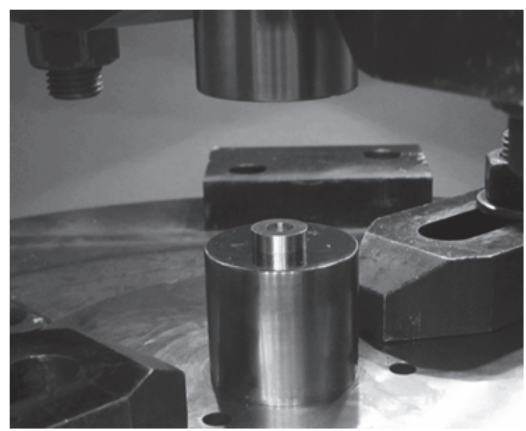

Figure 8 - Ring test samples (a) and ring compression process (b) [5]

Backward - forward hollow extrusion (Figure 9a) is another experimental method of friction determination. In this process, a cylinder-shaped billet is extruded and material flows both upwards and downwards [9]. The higher the friction, the more material flows upwards $\left(\mathrm{ratio}_{1} / \mathrm{h}_{2}\right.$ is friction sensitive). Theoretically, when friction is zero, equal amounts of the material flow up and down $\left(\mathrm{h}_{1}=\mathrm{h}_{2}\right)$. The main advantages of backward - forward hollow extrusion over ring test are that this test emulates severe plastic deformations that are more similar to real cold forming operations and that the test is more friction sensitive so lubricants can be easily compared based upon $\mathrm{h}_{1} / \mathrm{h}_{2}$ ratio [28].

a)

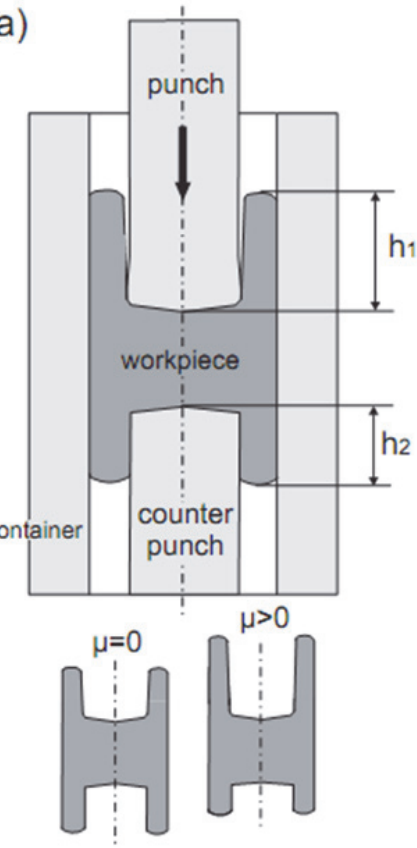

b)

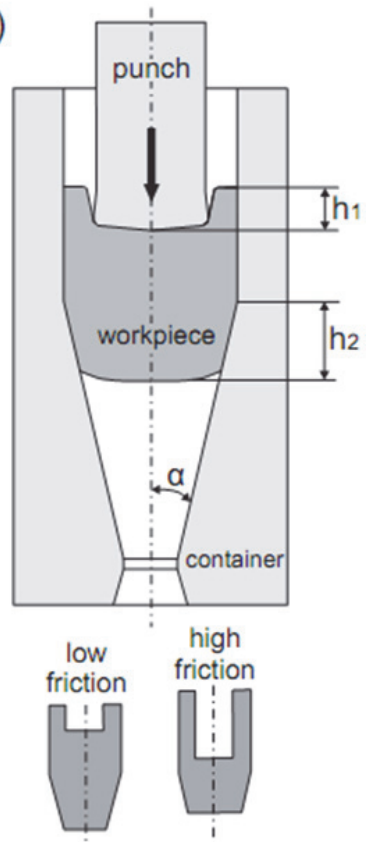

Figure 9 - Backward-forward hollow extrusion (a) and combined forward - backward extrusion (b) [9],[29] 
In combined forward - backward extrusion a cylindrical billet is extruded in the tool shown in Figure $9 \mathrm{~b}$. In low friction cases more material flows forward through the main opening in the die and in case of high friction, more material flows backwards through the gap between the tool and the die. Therefore, ratio $h_{1} / h_{2}$ is friction sensitive [9],[29],[30].

In forward bar extrusion (Figure 10) material is extruded in a standard forward extrusion die. Total extrusion load in this process consists of three components [31],[32]:

$F_{T}=F_{C}+F_{d}+F_{d d}$

where $F_{C}, F_{d}$ are forces required to overpower friction in cylindrical and conical die/billet contact surface and $\mathrm{F}_{\mathrm{dd}}$ is force needed for material deformation in conical segment.

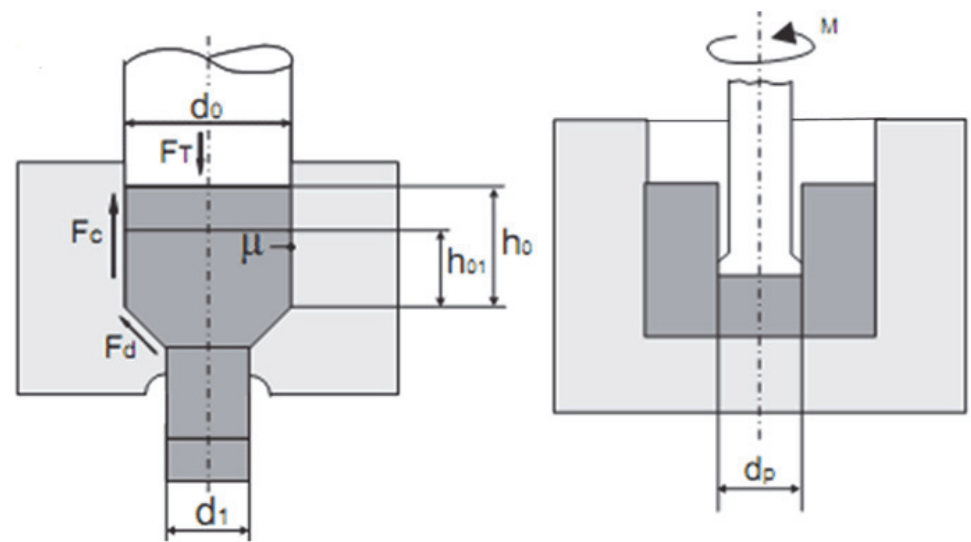

Figure 10 - Forward bar extrusion [31] and twist extrusion [33]:

During the complete extrusion process $F c$ decreases, while loads $F_{d}$ and $F_{d d}$ remain constant. Therefore the expression (4) can be transformed into:

$\Delta F_{T}=\Delta F_{c}+\Delta F_{d}+\Delta F_{d d}=\Delta F_{c}$

As forces $\Delta \mathrm{F}_{\mathrm{d}}$ and $\Delta \mathrm{F}_{\mathrm{dd}}$ are zero, equation (5) can be expressed:

$\Delta F_{c}=\Delta F_{T}=F_{T 0}-F_{T 1}$

From load - stroke diagram shown in Figure 11, load $\Delta \mathrm{F}_{\mathrm{T}}$ can be obtained.

$$
\Delta F_{c}=\Delta F_{T}=\mu \cdot \sigma \cdot \pi \cdot d_{0} \cdot\left(h_{0}-h_{01}\right)
$$

From (7), coefficient of friction is:

$$
\mu=\frac{\Delta F_{T}}{\sigma \cdot \pi \cdot d_{0} \cdot \Delta h}=\frac{\operatorname{tg} \alpha}{\sigma \pi d_{0}}
$$


a)

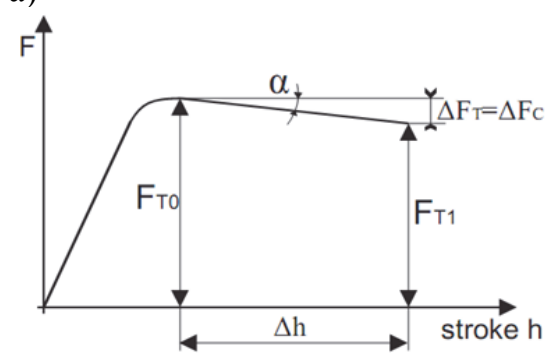

b)

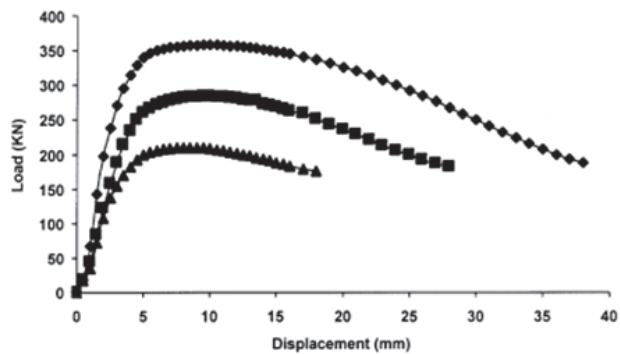

Figure 11 - Theoretical (a) and experimental (b) Load - stroke diagram of forward extrusion [34]

In twist extrusion (Figure 10b) cylindrical billet is backward extruded and then, at the end of extrusion process, the punch is rotated while the die is kept stationary. By using two different punches and by measuring momentum of rotation (M), friction can be calculated from following expression:

$\mathrm{m}=\frac{2 \sqrt{3}\left(M_{1}-M_{2}\right)}{\pi \cdot d_{p}^{2} \cdot h_{c} \cdot \sigma}$

where $d_{p}$ is the diameter of the punch, $h_{c}$ is the length of the punch land and $\sigma$ is flow stress of the material [33].

In T-shape compression, cylinder specimen is compressed by a flat punch and a die with a V-groove (Figure 12). During upsetting, material flows both in the die's groove and sideways between the punch and die. Material flow is the indicator of friction magnitude; the higher the friction, the more material flows to the side. After compression, either billet's height or width is measured and this data is imposed on friction diagram that is usually obtained by numerical simulation. Advantages of this test are that the tools are relatively cheap to build, lubricants can be easily applied and severe deformations are included [35].

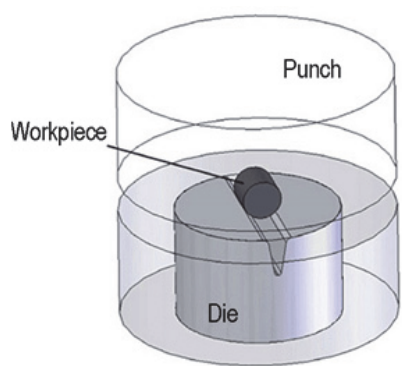

Set-up of test

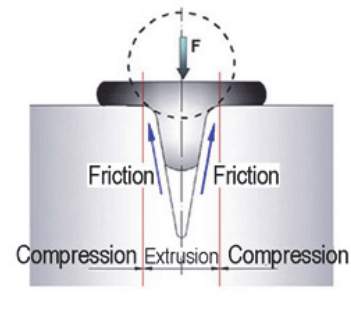

Deformation characteristic of specimen

Figure 12 - T-shape compression test [35]

Apart from bulk metal forming, there are also methods for friction determination in sheet metal forming, e.g. one friction test method for deep drawing is shown in [36].

Journal for Technology of Plasticity, Vol. 36 (2011), Number 1 


\section{PROPOSITION OF A NEW METHOD FOR FRICTION ESTIMATION IN BULK METAL FORMING}

In double - backward extrusion cylinder is backward extruded with a special punch with an opening through the centre (Figure 13). Material flows in two directions: a) through the side, between the punch and the die and b) through the central opening in the punch. Phenomenon of material flow is depended on the friction magnitude; the higher the friction, the more material flows through the central opening and vice versa, lower friction causes material flow more through the side gap (Figure 13).

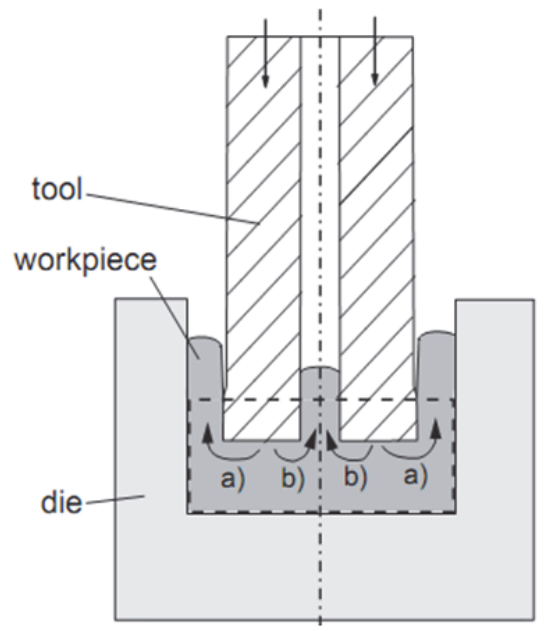

low friction

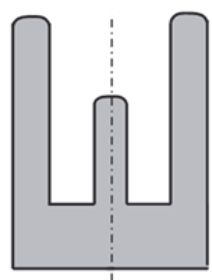

high friction

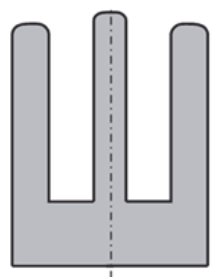

Figure 13 - Left: Double backward extrusion ( " $a$ " and " $b$ " are directions of material flow), Right: Material flow in low and high friction conditions [27]

In the experimental research of double - backward extrusion, punch with a hole $\phi 9 \mathrm{~mm}$ drilled through the center was used. Outer diameter of the punch was $\phi 28 \mathrm{~mm}$. Inner diameter of the die was $\phi 40,4 \mathrm{~mm}$ and dimensions of the billet were $\phi 40 \times 35 \mathrm{~mm}$.

In order to determine friction coefficient, friction calibration curves for this process were needed. FCC obtained by numerical simulation in software Simufact Forming 9.0 are shown in Figure 14. Material of the billet used in experiment as well as in numerical simulation was aluminium alloy with stress - strain curve: $K=315,2+117,1 \cdot \varphi^{0,2}[\mathrm{MPa}][37]$.

Preliminary simulations showed that material type has a fairly large influence of FCC, unlike in ring test, where this influence can be neglected.

Total stroke of $22 \mathrm{~mm}$ was conducted in both experiment and simulation. The black dot imposed on Figure 14 represents the height of bulge in experimental specimen for a given tool stroke (22 $\mathrm{mm}$ ). As it can be seen from Figure 14, friction coefficient in experiment was $\mu=0,12$, which corresponds very well with early expectations, as the billet was lubricated with oil.

Double backward extrusion is a very good method for friction determination due to large strains which occur in process, as well as due to very sensitive parameter (bulge height $\mathrm{h}_{1}$ ) on friction variation. Detailed theoretical and experimental investigation of double - backward extrusion is given in [37]. 


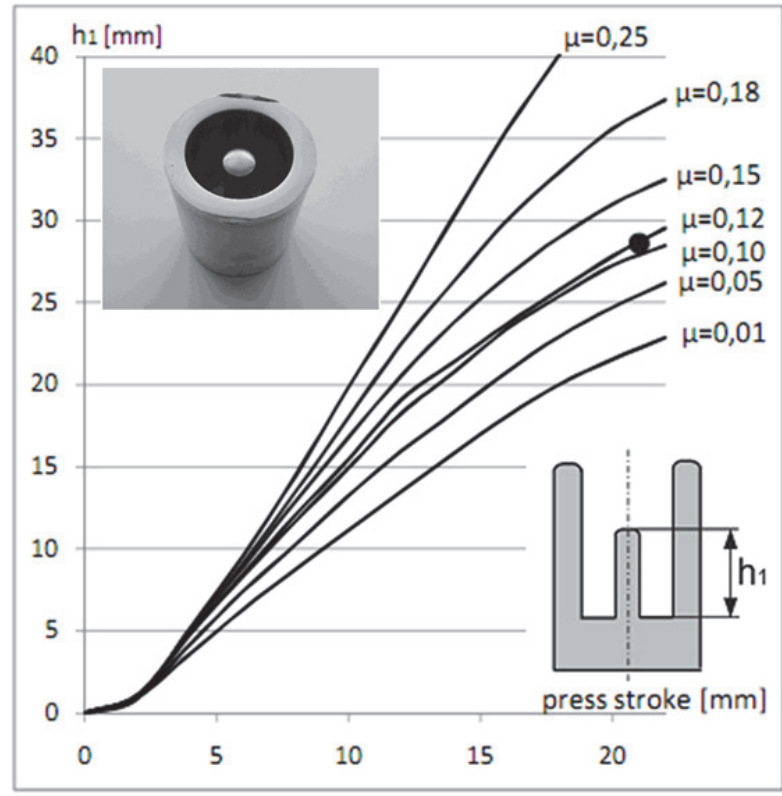

Figure 14 - Friction calibration curves obtained by Simufact Forming 9.0 [27]

\section{CONCLUSION}

Friction plays an essential role in all metal forming processes. This phenomenon affects forming load, material flow, workpiece surface quality, process temperature, cavity filling, etc. In order to theoretically analyze friction, several friction models have been developed: Coulomb friction model, Constant friction model, General friction model, etc. Each of the models has its advantages and setbacks and therefore, its field of application. For simulation of metal forming processes, it is essential to use an appropriate friction model, since using different models can substantially affect simulation's output results.

In order to estimate friction magnitude for specific lubrication and metal forming process, various experimental techniques have been developed. Some of them are presented in this paper. The most employed and theoretical analyzed model is ring - compression test. A short overview of this test is presented as well as friction calibration curves obtained by Male \& Cockroft, Avitzur and by numerical simulation in Simufact Forming 9.0 and Simufact Forming GP (ex Marc). Also the influence of ring' initial shape is analyzed by numerical simulation. Ring - compression test is not appropriate for processes where high strains and pressures prevail and therefore, others techniques are also used, such as: combined forward - backward extrusion, backward - forward hollow extrusion, twist extrusion, T-shape test... Summaries of these techniques are given in the paper. A new double backward extrusion method for friction evaluation is proposed. In this test, the billet is backward extruded with special punch with an opening through the centre. Therefore, material has the possibility to flow in two directions. Material flow phenomenon is friction sensitive; the higher the friction, the more material flows through the central opening. An experiment was conducted and result was imposed on FCC obtained by numerical simulation. Estimated friction coefficient $(\mu=0,12)$ corresponds very well with expectations because oil was used as lubricant. 


\section{REFERENCES}

[1] Schey J.: Metal deformation processes: Friction and Libricaion, Marcel Dekker INC, New York, 1970.

[2] Lange K.: Handbook of metal forming, SME, Dearborn, Michigan, 1994.

[3] Wang Z. G.: Tribological approaches for green metal forming, Journal of Materials Processing Technology 151, 2004, pp 223-227.

[4] Bay N., Azushima A., Groche P., Ishibashi I., ,Merklein M., Morishita M.: Environmentally Benign Tribo-systems for Metal Forming. CIRP Annals - Manufacturing Technology, vol. 59, no. 2, 2010, pp 760-780.

[5] Skakun P., Plančak M., Vilotić D., Milutinović M., Movrin D., Lužanin O.: Comparative investigation of different lubricants for bulk metal forming operations, DEMI 2011, Banja Luka, 2011.

[6] Arentoft, M., Bay, N., Tang, P.T., Jensen, J.D.: A New Lubricant Carrier for Metal Forming. CIRP Annals - Manufacturing Technology, vol. 58, no.1, 2009, pp 243-246.

[7] Petersen S.B., Martins P.A.F., Bay N.: Friction in bulk metal forming: a general friction model vs. the law of constant friction, Journal of Material Processing Technology 66, 1997, pp 186-194.

[8] Tan X.: Comparisons of friction models in bulk metal forming, Teratology International 35, 2002, pp 385-393.

[9] Fereshteh-Saniee F., Pillinger I., Hartley P.: Friction modeling for the physical simulation of the bulk metal forming processes, Journal of Material Processing Technology 153-154, 2004, pp 151-156.

[10] Joun M.S., Moon H. G., Choi I. S., Lee M. C., Jun B. Y.: Effects of friction on metal forming processes, Tribology International 42, 2009, pp 311-319.

[11] Bay N., Wanheim T.: Real area of contact and friction stress at high pressure sliding contact, Wear, 38, 1976, pp 201-209.

[12] Bašić H.: Friction models comparison in finite volume method simulation of bulk metal forming technologies, Journal for Technology of Plasticity, Vol. 33, Nr 1-2, 2008, pp 113123.

[13] Kunogi M.: On plastic deformation of hollow cylinders under axial compressive loading, Rep. Sci. Res. Inst. Tokyo, 1954, pp 63-92.

[14] Male A.T., Cockroft M.G.: A Method for the determination of the coefficient of friction on metals under conditions of bulk plastic deformation, Journal of the Institute of Metals, Vol. 93, 65, 1964.

[15] Avitzur B.: Metal Forming Processes and Analysis, McGraw-Hill, 1968.

[16] Hawkyard J.B., Johnson W.: An analysis of the changes in geometry of a short hollow cylinder during axial compression, Int. J. Sci. Pergamon Press Ltd., Vol. 9, 1967, pp 168-182.

[17] Sofuoglu H., Rasty J.: On the measurement of friction coefficient utilizing the ring compression test, Tribology International 32, 1999, pp 327-335.

[18] Abdul N.A.: Friction determination during bulk plastic deformation of metals, Annals of the CIRP, Vol. 30/1/, 1981, pp 143-146.

[19] Tan X., Martins P. A. F., Bay N., Zhang W.: Friction studies at different normal pressures with alternative ring-compression tests, Journal of Materials processing technology 80-81, 1998, pp 292-297.

[20] Dutton R. E., Seetharaman V., Goetz R. L., Semiatin S. L.: Effect of flow softening on ring test calibration curves, Materials Science and Engineering A270, 1999, pp 249-253. 
[21] Burgdorf M.: Über die Ermittlung des Reib-wertes für Verfahren der Massivum-formung durch den Ringstauchversuch, Industrie Anzeiger, 1967, pp 15-20.

[22] Mielnik E.: Metalworking Science and Engineering, McGraw-Hill, 1991.

[23] Plančak M., Barisić B., Vilotić D., Kačmarčik I., Movrin D., Skakun P., Milutinović M.: Analytical and numerical solutions for friction calibration curves (FCC) in bulk metal forming, CA systems in production planning 1, vol 12, 2011, pp 107-112.

[24] Plančak M., Vilotić D., Stefanović M., Kačmarčik I., Movrin D.: A contribution to the modeling of ring compression test for determination of friction in bulk metal forming processes, Balkan Trib, Thessaloniki, 2011, accepted paper.

[25] Shen G., Vedhanayaga A., Kropp E., Altan T.: A method for evaluating friction using a backward extrusion-type forging, Journal of Materials Processing Technology 33, 1992, pp 109-123.

[26] Kačmarčik I., Movrin D., Lužanin O., Skakun P., Plančak M., Vilotić D.: Determination of friction in bulk metal forming processes, $12^{\text {th }}$ International conference on tribology, Kragujevac, 2011, pp 111-116.

[27] Plančak M., Movrin D., Kačmarčik I., Čupković Đ.: Proposal of a new friction testing method for bulk metal forming, $34^{\text {th }}$ International conference on production engineering, Nis 2011, accepted paper.

[28] Timothy Schrader, Manas Shirgaokar, Taylan Altan: A critical evaluation of the double cup extrusion test for selection of cold forging lubricants, Journal of Materials Processing Technology, vol. 189, 2007, pp 36-44.

[29] Kuzman K. Pfeifer E., Bay N., Hundig J., Control of material flow in a combined backward can - forward rod extrusion, Journal of Materials Processing Technology 60, 1996, pp 141147.

[30] Bay N., Hunding J., Kuzman K., Pfeifer E.: A study of the double-cup extrusion process as a friction test, Proceedings of the Fifth ICTP, Ohio, vol. 1, 1996, pp 311-318.

[31] M. Bakhshi-Jooybari: A theoretical and experimental study of friction in metal forming by the use of the forward extrusion process, Journal of Material Processing Technology 125-126 2002, pp. 369-374.

[32] Marinković V., Marinković T.: Odredjivanje koeficijenta trenja u procesima obrade istiskivanjem, $11^{\text {th }}$ Int. conference on Tribology - Serbiatrib, 2009.

[33] Bay N., Wibom O., Nielsen J. Aa.: A new friction and lubrication test for cold forging, Annals of the CIRP Vol. 44/1, 1995.

[34] Wagener H. W., Wolf J.: Coefficient of Friction in Cold Extrusion, Journal of Material processing technology 44, 1994, pp 283-291.

[35] Zhang Q.: Evaluation of friction conditions in cold forging by using T-shape compression test, Journal of Materials Processing Technologies, Vol 209., 2009, pp 5720-5729.

[36] Hu Z., Vollertsen F.: A new friction test method, Journal for Technology of Plasticity, Vol. 29, Nr 1-2, 2004, pp 1-10.

[37] Čupković Đ.: Prilog istrazivanju procesa dvostrukog suprotnosmernog istiskivanja, Magister work (in Serbian), Novi Sad, 2005. 


\title{
PRILOG ISTRAŽIVANJU FENOMENA TRENJA U TEHNOLOGIJI ZAPREMINSKOG PLASTIČNOG DEFORMISANJA
}

\author{
Igor Kačmarčik, Dejan Movrin, Aljoša Ivanišević
}

Univerzitet u Novom Sadu, Fakultet tehničkih nauka, Srbija

\begin{abstract}
REZIME
Trenje je pojava koja nastaje usled relativnog kretanja jednog tela u odnosu na drugo. $U$ tehnologijama plastičnog deformisanja trenje predstavlja nepoželjan, ali u isto vreme i neizbežan fenomen. Trenje ima negativan uticaj na sve glavne parametre procesa, a takođe i na sam kvalitet radnog komada. Kako bi se dobili tačni rezultati u eksperimentima i simulacijama kod plastičnog deformisanja, neophodno je veoma dobro poznavanje pojave trenja u datim uslovima. Za kvantifikaciju trenja razvijeni su brojni modeli, od kojih su najviše u primeni Coulomb-ov model, model konstantnog trenja i generalni model trenja. Svaki od ovih modela ima svoje područje primene. Postoji nekoliko razvijenih tehnika za određivanje veličine trenja. Neke od njih su prikazane u radu: sabijanje prstena, istosmerno istiskivanje, kombinovano šuplje istiskivanje, istiskivanje sa rotacijom, itd. Takođe je u radu predložen $i$ novi metod za određivanje veličine trenja (dvostruko suprotnosmerno istiskivanje). U ovom metodu, obradak je istisnut pomoću specijalnog žiga sa otvorom kroz sredinu. Na taj način materijal teče $i$ kroz centralni otvor $i$ između žiga i matrice. Količina materijala koji protekne kroz centralni otvor je u korelaciji sa veličinom trenja koja vlada u procesu (što veće trenje, to višse materijala proteče kroz otvor). $\mathrm{Na}$ bazi ove činjenice konstruisan je etalon dijagram, koji omogućava određivanje veličine trenja u konkretnim uslovima.
\end{abstract}

Ključne reči: Modeli trenja, sabijanje prstena, kalibracione krive za trenje, dvostruko suprotnosmerno istiskivanje 